\title{
Bristol Stool Type 6
}

National Cancer Institute

\section{Source}

National Cancer Institute. Bristol Stool Type 6. NCI Thesaurus. Code C125399.

Mushy pieces with ragged edges. 